\title{
Glucomanan Extract From Salak Seed (Salacca edulis Reinw.) As An Alternative Material of Making Hard Capsule Shell
}

\author{
Triana Yunita*1, Dharmawan Yudha Rizky, Utami Putri Rahajeng, Kurniawan Fredy \\ ${ }^{1}$ Materials and Metallurgy Study Program, Kalimantan Institute of Technology, Balikpapan, Indonesia \\ *nita@itk.ac.id
}

\begin{abstract}
This research studied about making hard capsule shell using glucomannan extract from salak seed (Salacca edulis Reinw.). The glucomannan extracted by using etanol $96 \%$ and aqua $\mathrm{dm}$. The glucomannan that had been extracted will became KGM polymer that will be used for casting the hard capsule shell using petri cup. The results obtained by smashing the seeds of salak to be smooth with meat grinder and glucomannan extraction using 2 methods with etanol $96 \%$ and isopropyl alcohol. After extracting the seeds of salak seeds, the bacon seed flour is weighed and taken some samples to obtain the best composition, resulting in a film layer on a thick capsule shell like a capsule shell in general. The result of the printing on the petri cup is still a thin layer that can not be taken, but this proves that glucomannan contained in the seeds of salak able to produce lapisal film capsule shells with the right composition.
\end{abstract}

Keywords: Salak Seed (Salacca edulis Reinw.), glucomannan, hard capsule shell

\begin{abstract}
Abstrak
Penelitian ini bertujuan membahas proses pembuatan hard capsule shell menggunakan ekstrak glucomannan dari biji salak (Salacca edulis Reinw.). Glucomannan diekstraksi dengan menggunakan etanol 96\%. Glucomannan yang telah diekstraksi akan menjadi polimer KGM yang akan digunakan untuk pengecoran kulit kapsul keras menggunakan cawan petri. Hasil yang diperoleh dengan menghancurkan benih salak menjadi halus dengan penggiling daging dan ekstraksi glukomanan menggunakan 2 metode dengan etanol 96\% dan isopropil alkohol. Setelah mengekstraksi buah salak, tepung biji bacon ditimbang dan diambil beberapa sampel untuk mendapatkan komposisi terbaik, menghasilkan lapisan film pada cangkang kapsul tebal seperti kapsul pada umumnya. Hasil cetak pada cawan petri berupa lapisan tipis yang tidak bisa diambil, tetapi hal ini membuktikan bahwa glucomannan yang terkandung dalam biji salak mampu menghasilkan lapisan kapsul lapisal dengan komposisi yang tepat.
\end{abstract}

Keywords: Salak Seed (Salacca edulis Reinw.), glucomannan, hard capsule shell

\section{Introduction}

Capsule shells, wrapping and protective drugs, are the most important part in pharmaceutical packaging. In general, the capsule shell used today is made of almost $70 \%$, gelatin base material and the remainder are other materials such as dyes, glycerol and water. Gelatin gel has the properties of melt at $35^{\circ} \mathrm{C}$, caused by damage caused by disruption of hydrogen bond on gelatin molecule. This property causes gelatin gel to melt in the biological fluid in the body which has an average temperature of $30^{\circ} \mathrm{C}$ (Ducinseille, et al., 2015).

Gelatin mades from tissues in the animal's body. The largest source of gelatin production is pig skin (46\%). In addition to pigs, gelatin can also be obtained from cows $(29.4 \%)$, bovine bones $(23.1 \%)$, and fish (1.5\%). So far, the most commonly used gelatin in the food and pharmaceutical industries is cow and pork gelatin. This causes concern for Muslims if the gelatin used is gelatin from pig skin. (Jones, et al., 2012) To eliminate these concerns, a study was conducted to substitute the basic ingredients of pig gelatin. In 2010, Tabakha mentioned that polymers such as HPMC (Hydroxypropyl Methylcellulose), plant derived material, can be used to replace gelatin in capsule shells (Chen et al., 2016b). This HPMC polymer can be found in glucomannan, a polysaccharide compound composed of D-mannosa $+67 \%$ and D-glucose $+33 \%$ (Koswara, 2009). Some studies have been made to gain 
glucomannan from some plants, such as iles-iles (Amorphophallus. Sp) (Koswara, 2009), palm kernel cake (Yopi, et al., 2006), and aloe vera (Retnowati \& Kumoro, 2012).

From the several plants, iles-iles or konjac plants have the highest glucomannan content. Based on Chinese professional standard, in konjac powder there is $85 \%$ konjac glukomannan (Tester \& AlGhazzewi*, 2016). However, the use of konjac bulbs has been done in many sectors. Chinese people use konjac glucomannan as an emulsifier in the food industry such as syrup, noodles, and edible food wrapping. Therefore, a study was conducted to obtain substitution of porang bulbs, as well as to maximize glucomannan as an alternative material for making capsule shells. According Nugroho (2014), flour seeds have a glukomanan content of 59.37\% in the form of hemicellulose. The rest, salak seeds have the main chemical content of carbohydrates consisting of $28.98 \%$ cellulose, as well as in one gram of bark contains 0.1637 grams of mannose and 0.0089 grams of glucose (Nugroho, 2014).

The salak seeds are part of the bark that is rarely used, even categorized as salak waste. This categorization occurs because the seeds of bark have a hard texture and not easily destroyed, so the processing of salak seeds is quite difficult (Supriyadi, et al., 2002). Therefore, through this research, trials of salak seed processing into salak seed meal, and then extraction of glucomannan content from the flour. It is expected that the realization of gelatin substitution as the basic ingredients of capsule shells, as well as the optimization of the use of glukomanan seeds of salak as a substitute material, with appropriate safety factors and can be a solution to the concerns of Muslims in medication.

\section{Research Methodology}

Research methodology are materials, methods, and parameters that were used.

\subsection{Materials}

The material used is the salak seeds taken from the salak fruit purchased on the market Pucang Surabaya as much as $20 \mathrm{~kg}, 96 \%$ Ethanol purchased from the shop Sip Surabaya, Aqua adm which has been provided by ITS halal study center.

\subsection{Preparation of Salak Seed Flour}

Preparation process for the manufacture of flour seeds is done by separating the seeds of bark from the skin and flesh of fruit, then the seeds that have been separated salak was washed with running water until clean. After that, the salak seeds that have been cleaned were broken down and ground into a seed shape of salak seed flour.

\subsection{Drying Method Oven}

Then the result of grinding the seeds was dried by using an oven with a temperature below $\leq 60{ }^{\circ} \mathrm{C}$. After the dried basil flour is put into the blender and mashed with a blender to the teng seeds bark turned into fine powders. Salak seed powder is then weighed in accordance with the experimental variables. Then the result of grinding the seeds was dried by using an oven with a temperature below $\leq 60{ }^{\circ} \mathrm{C}$. After the dried basil flour is put into the blender and mashed with a blender to the teng seeds bark turned into fine powders. Salak seed powder is then weighed in accordance with the experimental variables.

\subsection{Preparation of Glucomannan Extraction}

The preparation process for the manufacture of glucomannan extraction using filter paper. A total of 5 20 grams of salak seeds are fed into $96 \%$ ethanol solution and Aqua adm as much as $100 \mathrm{ml}$ with a 1 : $6(\mathrm{w} / \mathrm{v})$ prevelingan. After that stirring for 30 minutes and extracted by using filter paper. Repeat $3 \mathrm{x}$ repeat so that the polar and non-polar separation succeeds with each after the extract is completed, the drying or discharging of the liquid is emphasized using the Press machine tool. 


\subsection{Capsule Shell Making Method}

A solution of 1:20, 1:10 and 1: 5 composition between KGM and Aqua dm. The first 5-20 g of the KGM polymer is dissolved into $100 \mathrm{~mL}$ of Aqua dm with stirring for $2 \mathrm{~h}$ at a temperature below $60{ }^{\circ} \mathrm{C}$. In this way, a gel solution will be obtained. Then Then the kGM capsule is prepped by dipping the mold pin of stainless steel (capsule size: 0) into the gel-forming solution. Once cooled with room temperature, the capsule is dried in the freezer.

\subsection{FT-IR Analysis of KGM Polymer}

In this FT-IR test aims to find out the chemical structure formed from each specimen. Test results will be presented in graphical form. Where the graph will show how the arrangement of chemical structures will be formed.

\subsection{Surface Morphology of KGM Polymer}

In this SEM test aims to determine the phases formed from each specimen. Test results will be presented in the form of images with the morphological structure of the seeds of bark. Where the image will show the phases to be formed.

\subsection{Transparency of KGM Polymer Solution}

In this phase, UV-Vis Spectrophotometer testing is use to aims and determine the percentage of transparency of each specimen. Test results will be presented in graphical form. Where the graph will show the percentage of transparency that will be formed.

\section{Result and Discussion}

The results obtained until this stage is the work in finding the composition of the right salak seeds. This work is done by smashing the seeds of salak to be smooth with meat grinder and glucomannan extraction using 2 methods with etanol 96\% and isopropyl alcohol.
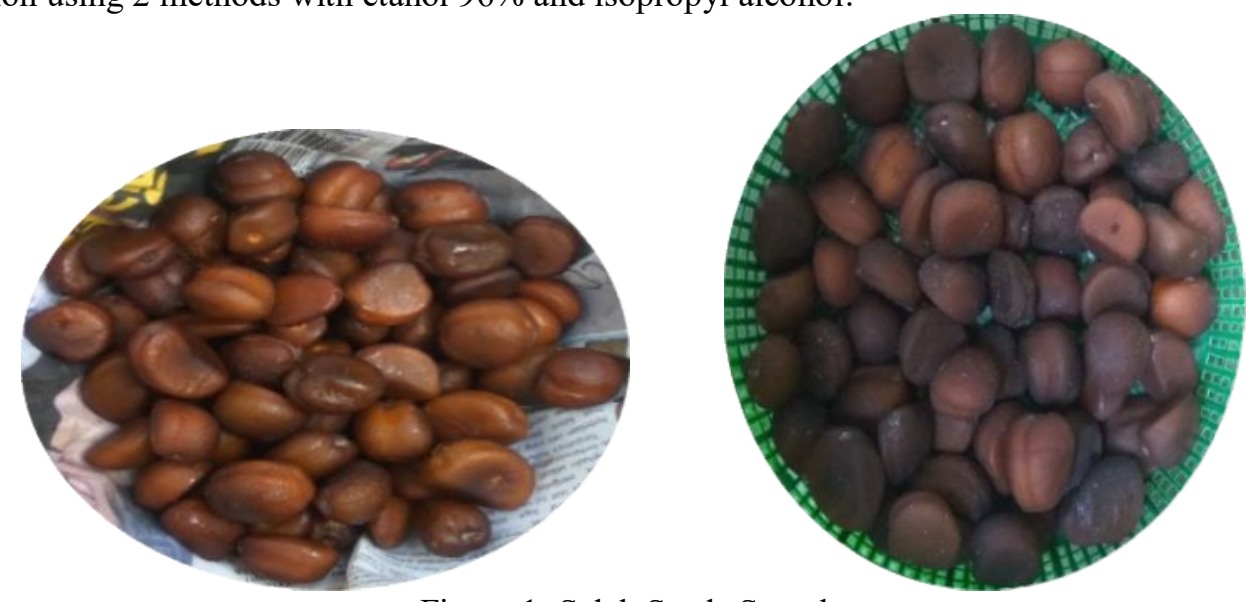

Figure 1. Salak Seeds Sample

Figure 1. shows the sample of salak seeds that will be crushed into smaller and more subtle sizes so they can be extracted and extracted glucomannan. 

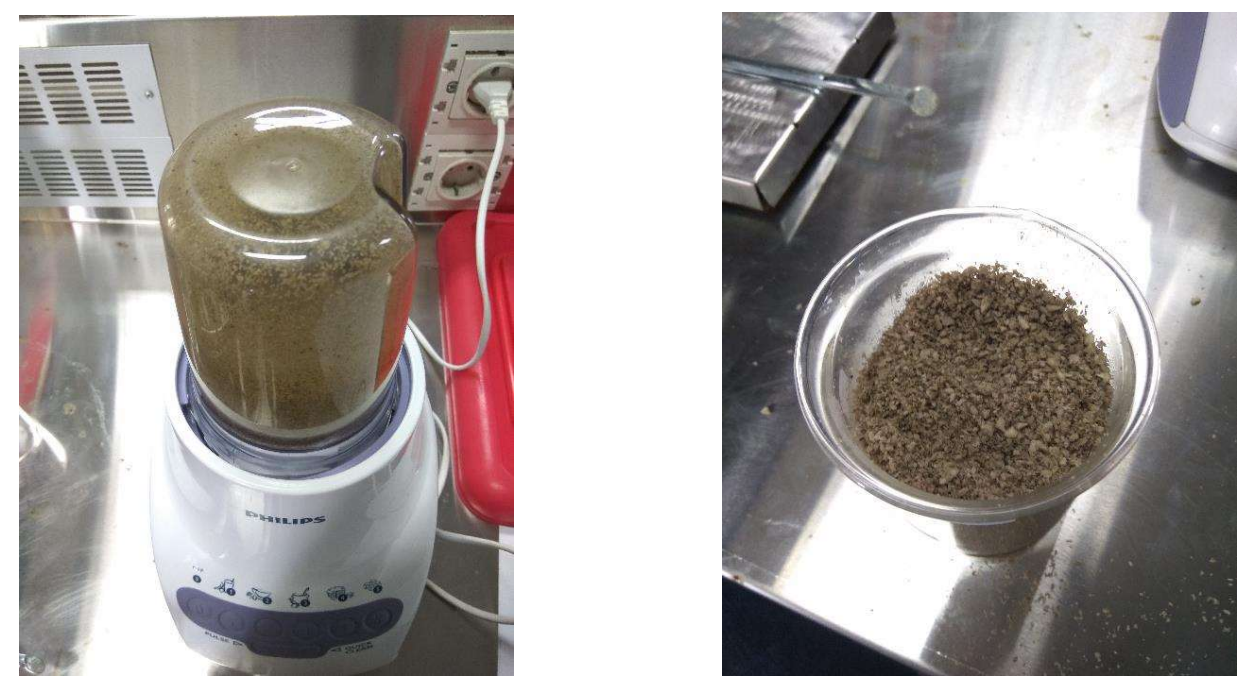

Figure 2. (a) Salak seeds crushing by using a coffee blender (b) Salak seeds that looks to be smooth

Figure 2 (b) is a salak seed that has been made to be more subtle so obtained in the form of flour seeds. Flour seeds will be dried in the oven with temperatures under " $60{ }^{\circ} \mathrm{C}$ " to be extracted glucomanannya so lose of its weight. To crush the seeds of salak, the preparation required a couple of time because after being removed from the salak fruit, the seeds of salak should be destroyed with a shell breaker, where the seeds are very very hard, so it must be smoothed in 3 ways that is broken with a capsule shell then beaten with a hammer until it becomes smaller, grinded with a meat grinder and blended in order to become a powder.

Some samples of the compositions that have been taken are 5, 20 and 30 grams as shown in Figure 3. Figure 4 shows 5 and 20 gram flour grains mixed with ethanol $52.1 \mathrm{ml}+47.9 \mathrm{ml}$ aqua dm at a ratio of 1: $6(\mathrm{w} / \mathrm{v})$ to the sample and stirred for $30 \mathrm{~min}$. After stirring, glucomannan extraction is carried out by pouring into a $50 \mathrm{ml}$ measuring cup which has been given filter paper to be cleaned from the impurities contained in the seeds of the bark. This repetition is done as much as 3 times so that the seeds of barked salak obtained and done printing will be clean from other impurities.

After extracting the seeds of salak seeds, the bacon seed flour is weighed and taken some samples to obtain the best composition, resulting in a film layer on a thick capsule shell like a capsule shell in general.
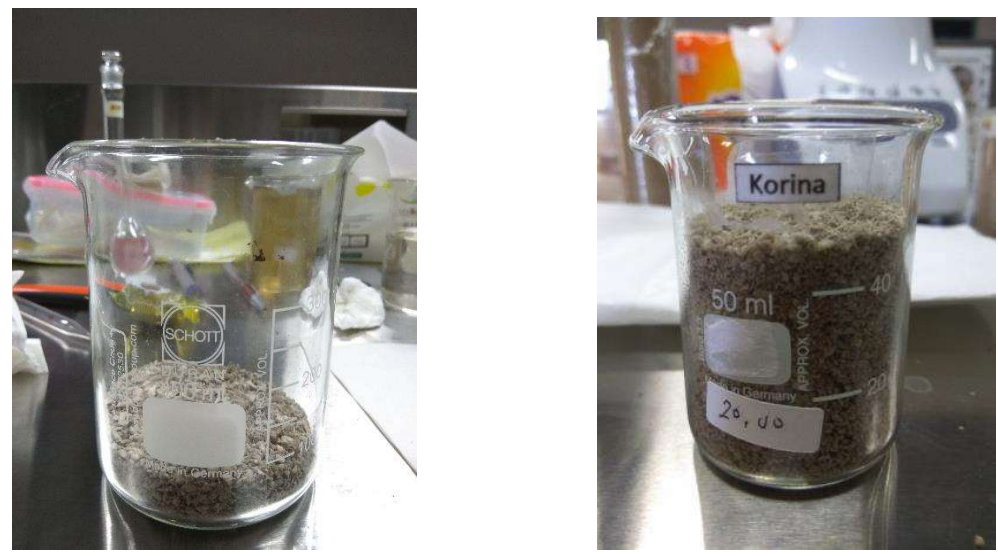

Figure 3. Sample of seed flour (a) 5 gram (b) 20 gram 

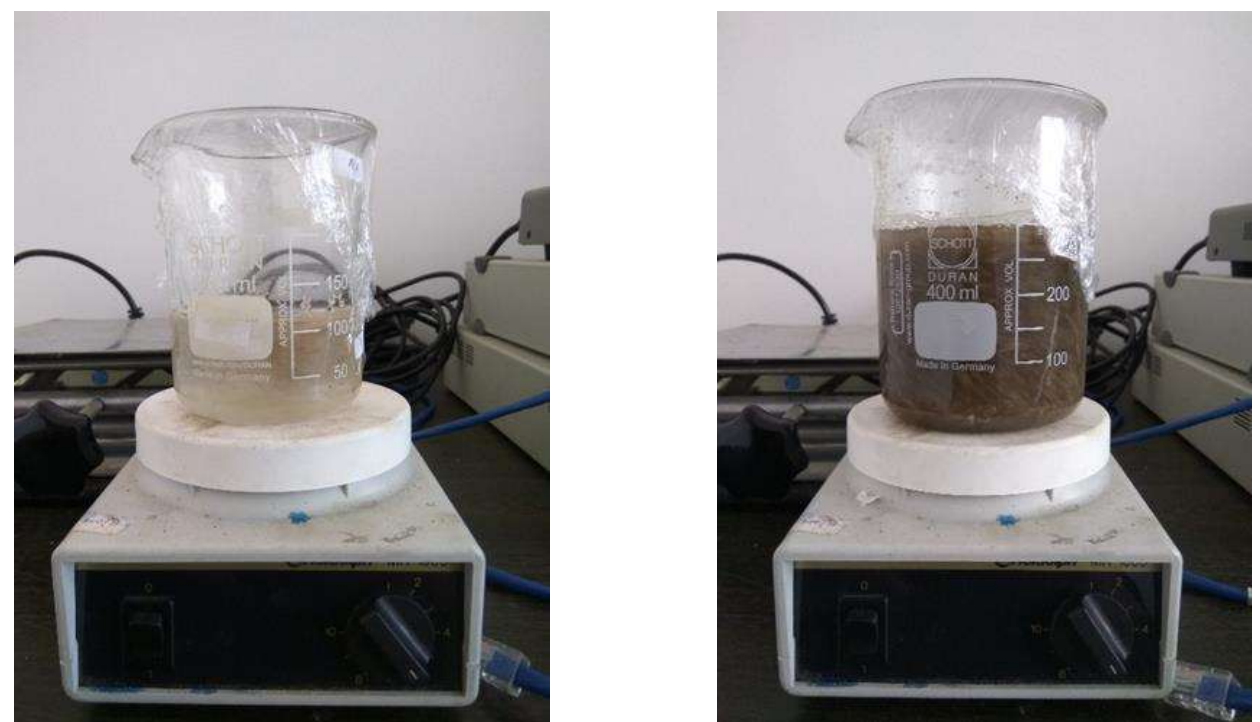

Figure 4. (a) 5 grams of salak seed flour which has been added $100 \mathrm{ml}$ of alcohol solution $96 \%+$ Aqua $\mathrm{dm}$ and stirring for 30 minutes (b) 20 grams of basil flour which has been added $100 \mathrm{ml}$ of $96 \%$ alcohol + Aqua $\mathrm{dm}$ and stirring for 30 minutes

After getting some samples, then the sample is mixed with aqua $\mathrm{dm} 100 \mathrm{ml}$ and done stirring for 2 hours so get the solution with glucomanan content inside which is used to print the capsule shells as in Figure 5 .
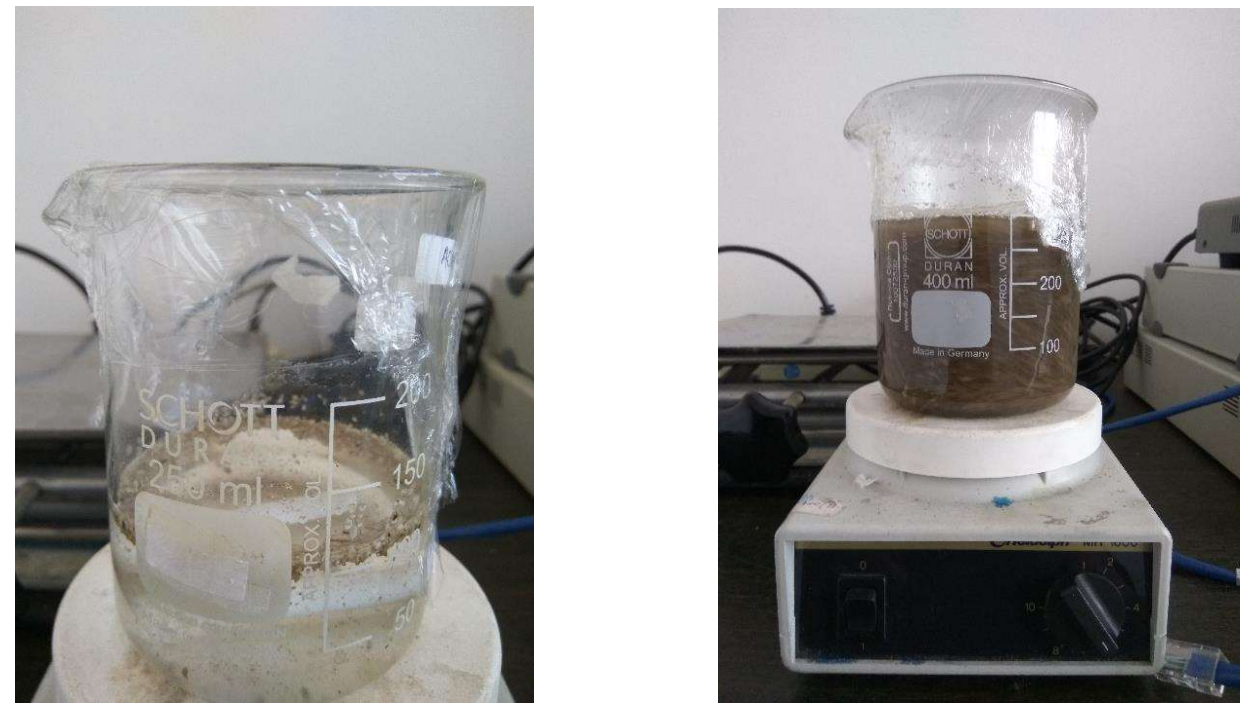

Figure 5. (a) Glucomannan solution obtained from 5 grams of salak seed flour + aqua adm and stirring for 2 hours. (b) Glucomannan solution obtained from 20 grams of salak seed flour + aqua adm and stirring for 2 hours.

From the 5 grams of stirring, the molding is poured into a petri dish, after which it is dried in an oven with temperatures below $60{ }^{\circ} \mathrm{C}$ for $+4-5$ hours. After drying, the result of the printing on the petri dish is still a thin layer that can not be taken, but this proves that glucomannan contained in the seeds of salak able to produce lapisal film capsule shells with the right composition. 

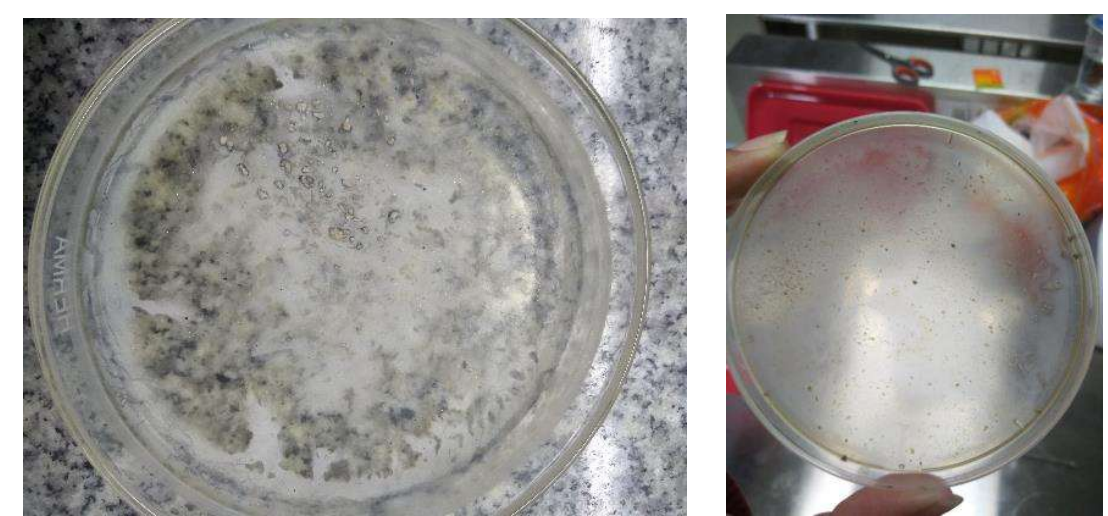

Figure 6. a) Layers of film in print using 5 grams of salak seed flour in petri dish with a very thin layer b) Layers of films in print by using 20 grams of banana seed flour in petri dishes with a thicker layer and flat on the surface of the cup

\section{Conclusion}

The results of a temporary study that can be achieved by a team of researchers up to this stage of glucomannan contained in the seeds of salak can be a mold layer of plastic film from capsule shells. This film layer can become thicker after being refined when the correct composition is required to print the film coating. In making the capsule shell is still constrained because it is in the order stage.

\section{References}

Koswara, S., 2009. Modul Teknologi Pengolahan Umbi-Umbian, Bagian 2. Pengolahan Umbi Porang., Bogor: SEAFAST Center Research and Community Service Institution IPB.

Nugroho, D., 2014. Studi Potensi Biji Salak (Salacca edulis Reinw) Sebagai Sumber Alternatif Monosakarida Dengan Cara Hidrolisis Menggunakan Asam Sulfat., Yogyakarta: Fakultas Teknologi Pertanian Universitas Gadjahmada.

Retnowati, S. \& Kumoro, C., 2012. Manan precipitation from aloe vera leaf pulp juice using methanol and isopropyl alcohol as anti-solvent: experimental and empirical modelling approach. Reaktor, Issue 14(1), pp. 46-50.

Supriyadi, et al., 2002. Changes in The Volatile Compounds and in The Chemical and Physical Properties Of Snake Fruit (Salacca edulis Reinw) Cv. Pondoh during maturation. J Agric Food Chem, Issue 50(26), pp. 7627-7633.

Tester, R. \& Al-Ghazzewi*, F., 2016. Glucomannans and Nutrition. Food Hydrocolloids, pp. 1-9.

Yopi, P. A., Thontowi, A., Hermansyah, H. \& Wijarnako, A., 2006. Preparasi mannan dan mannanase kasar dari bungkil kelapa sawit. Jurnal Teknologi, Volume 4, pp. 312-319. 